\title{
Bioavailability of Some Heavy Metals in Selected Dumpsites in Ozoro, South-South, Nigeria
}

\author{
C. K Ojebah ${ }^{1}$ and A. Uwague ${ }^{2}$
}

\author{
Department of Science Laboratory Technology, Delta state Polytechnic, P. M. B. 5, Ozoro
}

\begin{abstract}
This study investigated the concentrations and distribution patterns of some heavy metals in soil around some waste dumpsites in Ozoro, South-South, Nigeria. Two different dumpsites located at Kwale road and Owhelogbo roads in Ozoro were used for this study. Soil samples were collected at $0-15 \mathrm{~cm}$ depth. A total of two composite samples were collected for this study. The soil samples were air dried, sieved and digested. Sequential extraction was used to separate metals into their various geochemical fractions. Atomic absorption spectrophotometer (Bulk 200 model) was used to determine the metal concentrations in the various geochemical fractions. Physicochemical characteristics like $\mathrm{pH}$ and electrical conductivity were determined. $\mathrm{pH}$ result ranged from 9.6-10.3. The $\mathrm{pH}$ values were basic in both sampling sites. The conductivity result for both sites was $81.0 \mu \mathrm{S} / \mathrm{cm}$. The metal concentrations ranged from 0.29 - $0.53 \mathrm{mg} / \mathrm{kg}$ for Iron; $0.22-0.47 \mathrm{mg} / \mathrm{kg}$ for Copper; 0.16 - $0.21 \mathrm{mg} / \mathrm{kg}$ for Cadmium; 0.28 - $0.29 \mathrm{mg} / \mathrm{kg}$ for Zinc and 0.24 - $0.27 \mathrm{mg} / \mathrm{kg}$ for Manganese. The concentration of metals in both sites is in the order $\mathrm{Fe}>\mathrm{Cu}>\mathrm{Pb}>\mathrm{Zn}>\mathrm{Mn}>\mathrm{Cd}$ for Kwale road and $\mathrm{Pb}>\mathrm{Fe}>\mathrm{Zn}>\mathrm{Mn}>\mathrm{Cu}>\mathrm{Cd}$ for Owhelogbo road.
\end{abstract} Bioavailability results showed zinc, copper, cadmium, manganese, and lead more associated with the exchangeable fraction for Kwale road while zinc, copper, cadmium, lead and iron were associated more to the carbonate bound fraction for Owhelogbo road. However, lead and zinc associated more with both the carbonate bound and the exchangeable fractions for both sampling sites. There were significant variations in metal concentration from both sites. The mobility factors of metals in the soil profile follows in the order: $\mathrm{Cd}>\mathrm{Mn}>\mathrm{Cu}>\mathrm{Pb}>\mathrm{Zn}>\mathrm{Fe}$.

Keywords- Bioavailability, fraction, heavy metals, pollution, sampling, sites.

\section{INTRODUCTION}

Ozoro is a fast developing town in South-South, Nigeria with a corresponding increase in population leading to increased waste generation. As a result of increased activities occasioned by population growth, dumpsites are proliferated all over the town. Wastes are often deposited at open dumpsites and poor management of these sites could create a number of adverse environmental impacts (Ekwulumgbo et al., 2013). Risks associated with these waste are categorized into three: biological, chemical and physical (Wuana et al., 2012).

Heavy metals are chemical elements mostly with density greater than $4 \mathrm{~g} / \mathrm{cm}^{3}$ found in all kinds of soils, rocks and water in fresh water ecosystem (Adelekan and Abegunde, 2011).Elements of interest exist in several different forms and are associated with a range of components in the soil which influence their reactivity and hence their mobility and bioavailability (Osakwe and Egharevba, 2008; Yobouet et al., 2010). Information about the physicochemical forms of the element is required for understanding their environmental behaviour (mobility pathways, bioavailability) (Osakwe and Egharevba, 2008). The levels of heavy metals in the environment have been seriously increased during the last decades due to human activities (Binet al., 2001). The presence of heavy metals in the environment is of great ecological significance owing to their toxicity at certain concentrations, translocations through the food chains and nonbiodegradability which is responsible for accumulation in the biosphere. The ecological effects of heavy metals in soil are closely related to the distribution of the species in the solid and liquid phases of the soil (Tokalioglu et al., 2003). Depending on their origin, trace elements exist in different mineral forms and chemical compounds and in different combinations with mineral and organic components of soil and sediments which may vary according to various conditions (Tokalioglu et al., 2003). The behaviour and biological impact of heavy metal pollutants in aquatic system is governed by factors such as adsorption, desorption, sedimentation, re-suspension, filtration, complexation, precipitation, solubilisation, biological uptake and excretion (Abehet al., 2007). Comprehensive knowledge of the interaction between the trace elements and the soil matrix is required to judge the environmental impact. The behaviour of the elements in the environment such as bioavailability, toxicity and distribution cannot be reliably predicted on the basis of their total concentration (Tokalioglu et al., 2003; Iwegbue, 2007). The knowledge of both the total concentration and chemical speciation is necessary to characterize the 
behaviour of heavy metals in soil (Osakwe and Egharevba, 2008). Chemical speciation is of interest in environmental analysis because the behaviour of trace elements in natural system depends on the forms as well as the amounts which are present (Kot and Namiesni, 2000; Yobout et al., 2010). Because the toxicity of heavy metals is related to their existing species, the speciation of heavy metals is attracting more attention (Omuku et al., 2009). Speciation of metal contaminated soils is important in developing viable and cost effective remediation strategies and in predicting mobility and bioavailability of the metals (Spark, 2003). Water soluble and exchangeable forms are considered readily mobile while metals incorporated into crystalline lattices of clay appears relatively inactive (Kabala and Singh, 2001). Metals precipitated as carbonates occluded in iron, manganese, and aluminium oxides or complexed with organic matter could be considered relatively active or firmly bound depending upon actual combination of physical and chemical properties of the soil (Omuku et al., 2009). Soil texture (clay), $\mathrm{pH}$, organic matter and Fe-Mn oxides have been found to be the most important soil properties and components influencing biological uptake of heavy metals (Oviasogie and Agbimien, 2003; Kabala and Singh, 2001). The process of mobility (distribution), transport and partitioning of trace metals is controlled by physical and biological characteristics of that system (Hlavay et al., 2004). In soil environment, metals occur in both the solid phase and aqueous phase (Uwumarongie et al., 2008). In solution, metals can exist as free ions or as various complexes associated with organic (e.g. carboxyl and phenolic) or inorganic (e.g. $\mathrm{OH}^{-}, \mathrm{SO}_{4}{ }^{2-}, \mathrm{CO}_{3}{ }^{2-}$ ) ligands. While in the solid phase it can be retained in organic or inorganic soil components by various sorption mechanism e.g. ion exchange or surface complexation. It can also exist as minerals or be co-precipitated with other minerals e.g. carbonates (Bernhard and Neff, 2001). The process of oxidation, reduction, adsorption, precipitation and desorption is determined by the concentration of ions in the soil. The extent to which the reactions occur is determined by the composition of the soil especially the amount and type of clay minerals, hydrous oxides and organic matter, soil $\mathrm{pH}$, redox status and the nature of the contaminants (Uwumarongie et al., 2008).

The pressing demand to know the various forms, in which metal exist in nature so as to ascertain their toxicity potential and mobility pattern cannot be overemphasized. Sequential extraction method is used to assess the distribution and mobility of heavy metals in soil (Ireneet al., 1998). Tessier et al., (1979) has been the most widely used method of sequential extraction. This present study is focused on the determination of Lead $(\mathrm{Pb})$, Iron $(\mathrm{Fe})$, Zinc $(\mathrm{Zn})$, Cadmium $(\mathrm{Cd})$, Copper $(\mathrm{Cu})$, and
Manganese (Mn) so as to predict their source, origin, toxicity and bioavailability tendencies.

\section{MATERIALS AND METHODS}

\section{Study Area}

Ozoro is the administrative headquarters of Isoko North Local Government area of Delta State. Ozoro is located at latitude $5^{\circ} 32^{\prime} \mathrm{I} 8^{\prime} ' \mathrm{~N}$ and longitude 6 12 '58' $\mathrm{E}$ (www.wikipedia.org). Ozoro is one of the fastest developing communities in Delta State probably because of the presence of the Delta State Polytechnic.

\section{Sampling and Sample Preparation}

Soil samples were collected from two dumpsites located at Ozoro, January, 2018 with the aid of soil auger at $0-15 \mathrm{~cm}$ depth (Ataikiruet al., 2008). The samples were kept in black polythene bag for onward transportation to the laboratory for heavy metal distribution analysis.The samples were air dried for four days at room temperature and large objects (sticks, stones) were removed accordingly (Asiagwu, et. al., 2007). The dried samples were crushed into fine powder using agate mortar sieved using a 100 mesh screen.

\section{pH Determination}

Soil $\mathrm{pH}$ was determined in water according to the method described by Uwumaronge et al (2008). Ten grams of soil were weighed into a $50 \mathrm{ml}$ beaker and $20 \mathrm{ml}$ of distilled water was then added. The soil/water mixture (ratio 1:2) was stirred with a glass rod intermittently for 30 minutes. The $\mathrm{pH}$ meter was then calibrated using buffer 4 and 7. The $\mathrm{pH}$ meter (Cyberson 20) was set with appropriate controls to $\mathrm{pH}$ 7.0. The electrodes were rinsed and subsequently immersed into soil/water mixture. The $\mathrm{pH}$ was recorded as $\mathrm{pH}\left(\mathrm{H}_{2} \mathrm{O}\right)$.

\section{Determination of Electrical Conductivity}

Electrical conductivity was measured in 1:5 ratio of soil to water with Electrical conductivity meter (Marton $407 \mathrm{~S} 214$ ) after calibration with $0.01 \mathrm{M} \mathrm{KCl}$ solution.

\section{Sequential Extraction}

The method employed for the speciation studies was that introduced by Tessier et al (1979). 1.00g of the sieved samples were used for the sequential extraction processes. A total of two samples representing the top soil of the dumpsites were investigated.

\section{Exchangeable Fractions}

The soil samples were extracted with $8.0 \mathrm{ml}$ of $1 \mathrm{M}$ sodium acetate ( $\mathrm{NaOAc}$ at $\mathrm{pH} 8.2$ ) in a Teflon beaker for 1 hour with continuous agitation.

\section{Bound to Carbonates}

The residue from exchangeable fractions was leached at room temperature with $8.0 \mathrm{ml}$ of $1 \mathrm{M} \mathrm{NaOAc}$ solution adjusted to $\mathrm{pH} 5.0$ with acetic acid (HOAc) with continuous agitation for 1 hour.

\section{Bound to Fe-Mn Oxides (Reducible)}


The residue from carbonate bound fractions was extracted with $20 \mathrm{ml}$ of $0.04 \mathrm{M} \mathrm{NH} \mathrm{NH}_{2} \mathrm{OH} . \mathrm{HCl}$ in $25 \%(\mathrm{v} / \mathrm{v})$ $\mathrm{HOAc}$ at temperature of $96 \pm 2^{\circ} \mathrm{C}$ with occasional agitation for 5 hours.

\section{Bound to Organic Matter (Oxidisable)}

$3.0 \mathrm{ml}$ of $0.02 \mathrm{M} \mathrm{HNO}_{3}$ and $5.0 \mathrm{ml}$ of $30 \% \mathrm{H}_{2} \mathrm{O}_{2}$ adjusted to $\mathrm{pH} 2$ with $\mathrm{HNO}_{3}$ was added to the residues from Reducible fractions and the mixture heated to $85^{\circ} \mathrm{C}$ for 2 hours with intermittent agitation. Another $3.0 \mathrm{ml}$ aliquot of $30 \% \mathrm{H}_{2} \mathrm{O}_{2}$ was then added and the mixture heated to $85^{\circ} \mathrm{C}$ for 3 hours with occasional agitation. After cooling, $5.0 \mathrm{ml}$ of $3.2 \mathrm{M} \mathrm{NH} \mathrm{NH}_{4} \mathrm{Oc}$ was added and sample was diluted to $20 \mathrm{ml}$ with deionised water and agitated continuously for 30 minutes. The addition of $\mathrm{NH}_{4} \mathrm{OAc}$ was designed to prevent the adsorption of extracted metal into the oxidized sediment.

\section{Residual}

The residues from oxidisable fractions were digested with $5 \mathrm{ml} \mathrm{HF}$ and $5 \mathrm{ml}$ aqua regia and filtered into a $50 \mathrm{ml}$ standard flask and made up to mark with deionised water.

Blanks for the successive steps were also prepared. The residues were filtered into a $50 \mathrm{ml}$ standard flask and made up to the mark with deionised water after digestion.

The stored supernatant solutions from the various fractions digest sample solutions as well as the blanks were analysed instrumentally for their metal contents using Atomic Absorption Spectrophotometer (Buck 200A model). Total metal concentration was taken as the sum of the metal in the fractions.

\section{RESULTS}

The results of heavy metals concentrations and bioavailability are presented in table $1-.3$ as well as the mobility index in table 4.

Table.1: Physicochemical and Toatal metal concentrations of soil around some waste dumpsites in Ozoro, Delta State (taken as the sum of fractions)

\begin{tabular}{|l|l|l|}
\hline Parameter & Kwale Road & Owhelogbo Road \\
\hline $\mathrm{pH}$ & 81.0 & 81.0 \\
\hline Electrical conductivity $(\mu \mathrm{S} / \mathrm{cm})$ & 9,6 & 10.3 \\
\hline $\mathrm{Zn}$ & $0.29 \pm 0.025$ & $0.28 \pm 0.035$ \\
\hline $\mathrm{Cu}$ & $0.47 \pm 0.040$ & $0.22 \pm 0.040$ \\
\hline $\mathrm{Cd}$ & $0.21 \pm 0.00$ & $0.16 \pm 0.010$ \\
\hline $\mathrm{Pb}$ & $0.39 \pm 0.040$ & $0.33 \pm 0.030$ \\
\hline $\mathrm{Mn}$ & $0.24 \pm 0.040$ & $0.27 \pm 0.035$ \\
\hline $\mathrm{Fe}$ & $0.53 \pm 0.020$ & $0.29 \pm 0.035$ \\
\hline
\end{tabular}

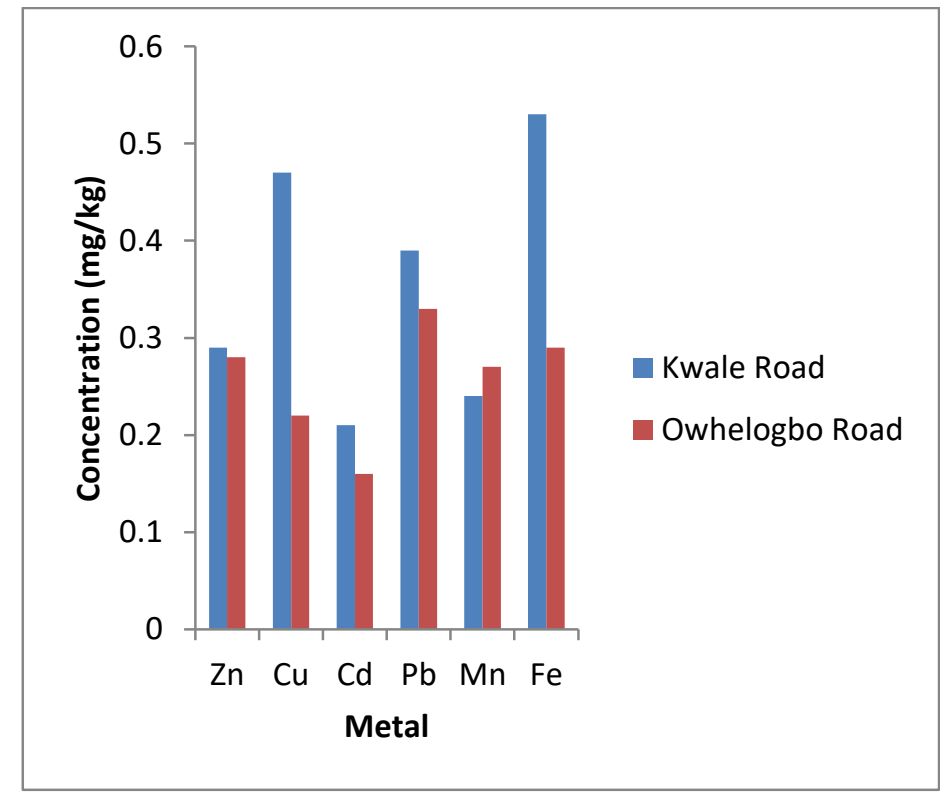

Fig.4.1: Bar Chart showing the concentration of $\mathrm{Zn}, \mathrm{Cu}, \mathrm{Cd}, \mathrm{Pb}, \mathrm{Mn}$ and Fe in Soil in two dumpsites in Ozoro, Delta State. 
Table.1: Bioavailability of $\mathrm{Zn}, \mathrm{Cu}, \mathrm{Cd}, \mathrm{Pb}$, Mnand $\mathrm{Fe}$ in $\mathrm{mg} / \mathrm{kg}$ in the various geochemical fractions of selected dump sites in Ozoro, Delta State.

\begin{tabular}{|c|c|c|}
\hline Metal/Fraction & Kwale Road & Owhelogbo Road \\
\hline \multicolumn{3}{|l|}{$\mathbf{Z n}$} \\
\hline Exchangeable & $0.10 \pm 0.005$ & $0.03 \pm 0.010$ \\
\hline Carbonate bound & $0.05 \pm 0.010$ & $0.09 \pm 0.010$ \\
\hline Fe-Mn Oxide & $0.07 \pm 0.000$ & $0.07 \pm 0.005$ \\
\hline Organic matter bound & $0.03 \pm 0.005$ & $0.05 \pm 0.010$ \\
\hline Residual & $0.04 \pm 0.005$ & $0.04 \pm 0.000$ \\
\hline Sum of extracted metal & $0.29 \pm 0.025$ & $0.28 \pm 0.035$ \\
\hline \multicolumn{3}{|l|}{$\mathbf{C u}$} \\
\hline Exchangeable & $0.13 \pm 0.010$ & $0.04 \pm 0.005$ \\
\hline Carbonate bound & $0.12 \pm 0.010$ & $0.06 \pm 0.010$ \\
\hline Fe-Mn Oxide & $0.11 \pm 0.010$ & $0.05 \pm 0.010$ \\
\hline Organic matter bound & $0.05 \pm 0.010$ & $0.03 \pm 0.010$ \\
\hline Residual & $0.06 \pm 0.000$ & $0.04 \pm 0.005$ \\
\hline Sum of extracted metal & $0.47 \pm 0.040$ & $0.22 \pm 0.040$ \\
\hline \multicolumn{3}{|l|}{ Cd } \\
\hline Exchangeable & $0.08 \pm 0.010$ & $0.02 \pm 0.005$ \\
\hline Carbonate bound & $0.04 \pm 0.005$ & $0.06 \pm 0.010$ \\
\hline Fe-Mn Oxide & $0.06 \pm 0.005$ & $0.05 \pm 0.005$ \\
\hline Organic matter bound & $0.01 \pm 0.010$ & $0.02 \pm 0.010$ \\
\hline Residual & $0.02 \pm 0.005$ & $0.01 \pm 0.000$ \\
\hline Sum of extracted metal & $0.21 \pm 0.035$ & $0.16 \pm 0.030$ \\
\hline \multicolumn{3}{|l|}{$\mathbf{P b}$} \\
\hline Exchangeable & $0.13 \pm 0.010$ & $0.05 \pm 0.000$ \\
\hline Carbonate bound & $0.14 \pm 0.010$ & $0.10 \pm 0.005$ \\
\hline Fe-Mn Oxide & $0.12 \pm 0.005$ & $0.08 \pm 0.010$ \\
\hline Organic matter bound & $0.06 \pm 0.010$ & $0.06 \pm 0.005$ \\
\hline Residual & $0.07 \pm 0.005$ & $0.04 \pm 0.010$ \\
\hline Sum of extracted metal & $0.39 \pm 0.040$ & $0.33 \pm 0.030$ \\
\hline \multicolumn{3}{|l|}{ Mn } \\
\hline Exchangeable & $0.09 \pm 0.005$ & $0.04 \pm 0.005$ \\
\hline Carbonate bound & $0.05 \pm 0.010$ & $0.09 \pm 0.010$ \\
\hline Fe-Mn Oxide & $0.05 \pm 0.010$ & $0.08 \pm 0.005$ \\
\hline Organic matter bound & $0.02 \pm 0.005$ & $0.04 \pm 0.010$ \\
\hline Residual & $0.03 \pm 0.010$ & $0.02 \pm 0.005$ \\
\hline Sum of extracted metal & $0.24 \pm 0.040$ & $0.27 \pm 0.035$ \\
\hline \multicolumn{3}{|l|}{ Fe } \\
\hline Exchangeable & $0.12 \pm 0.000$ & $0.03 \pm 0.010$ \\
\hline Carbonate bound & $0.13 \pm 0.005$ & $0.09 \pm 0.005$ \\
\hline Fe-Mn Oxide & $0.11 \pm 0.005$ & $0.08 \pm 0.005$ \\
\hline Organic matter bound & $0.08 \pm 0.010$ & $0.05 \pm 0.010$ \\
\hline Residual & $0.09 \pm 0.000$ & $0.04 \pm 0.005$ \\
\hline Sum of extracted metal & $0.53 \pm 0.020$ & $0.29 \pm 0.035$ \\
\hline
\end{tabular}

Table.2: \% Bioavailability of $\mathrm{Zn}, \mathrm{Cu}, \mathrm{Cd}, \mathrm{Pb}, \mathrm{Mg}$ and $\mathrm{Fe}$ in the various geochemical fractions of selected dump sites in Ozoro, Delta State.

\begin{tabular}{|l|l|l|}
\hline Metal/Fraction & Kwale Road & Owhelogbo Road \\
\hline $\mathbf{Z n}$ & & \\
Exchangeable & 34.48 & 10.71 \\
\hline Carbonate bound & 17.24 & 32.14 \\
\hline
\end{tabular}




\begin{tabular}{|l|l|l|}
\hline Metal/Fraction & Kwale Road & Owhelogbo Road \\
\hline Fe-Mn Oxide & 24.14 & 25.00 \\
\hline Organic matter bound & 10.35 & 17.86 \\
\hline Residual & 13.79 & 14.29 \\
\hline $\begin{array}{l}\text { Cu } \\
\text { Exchangeable }\end{array}$ & 27.66 & 18.18 \\
\hline Carbonate bound & 25.53 & 27.27 \\
\hline Fe-Mn Oxide & 23.40 & 22.73 \\
\hline Organic matter bound & 10.64 & 13.64 \\
\hline Residual & 12.77 & 18.18 \\
\hline $\begin{array}{l}\text { Cd } \\
\text { Exchangeable }\end{array}$ & 38.10 & \\
\hline Carbonate bound & 19.05 & 12.50 \\
\hline Fe-Mn Oxide & 28.57 & 37.50 \\
\hline Organic matter bound & 4.76 & 31.25 \\
\hline Residual & 9.52 & 12.50 \\
\hline Pb & & 6.25 \\
\hline Exchangeable & 25.00 & \\
\hline Carbonate bound & 26.92 & 15.15 \\
\hline Fe-Mn Oxide & 23.08 & 30.30 \\
\hline Organic matter bound & 11.54 & 24.24 \\
\hline Residual & 13.46 & 18.18 \\
\hline $\begin{array}{l}\text { Mn } \\
\text { Exchangeable }\end{array}$ & 37.50 & 12.12 \\
\hline Carbonate bound & 20.83 & 14.81 \\
\hline Fe-Mn Oxide & 20.83 & 33.33 \\
\hline Organic matter bound & 8.33 & 29.63 \\
\hline Residual & 12.50 & 14.81 \\
\hline $\begin{array}{l}\text { Fe } \\
\text { Exchangeable }\end{array}$ & 22.64 & 7.41 \\
\hline Carbonate bound & 24.53 & 10.34 \\
\hline Fe-Mn Oxide & 20.75 & 31.03 \\
\hline Organic matter bound & 15.09 & 27.59 \\
\hline Residual & 16.98 & 17.24 \\
\hline & & 13.79 \\
\hline
\end{tabular}

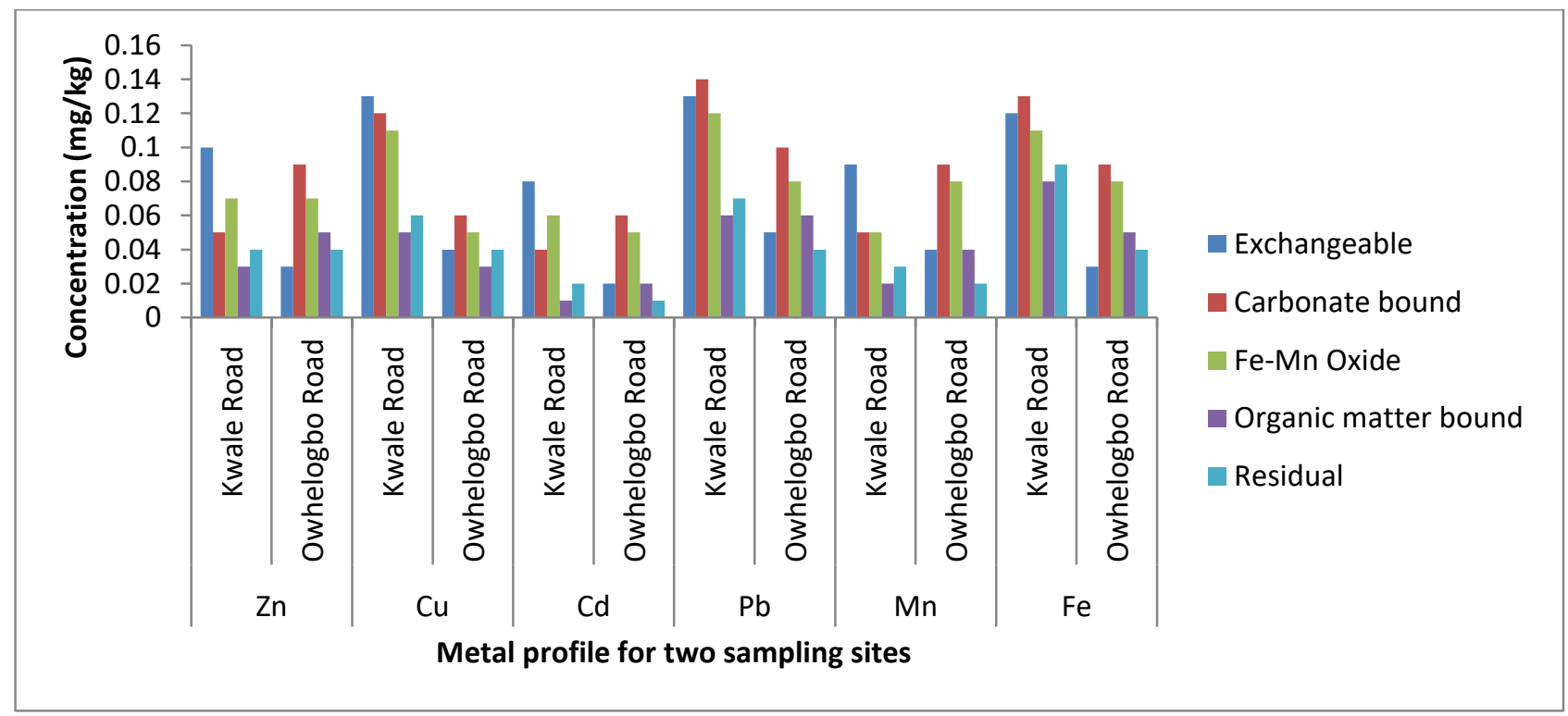

Fig.2: Bar chart showing the Bioavailability of $\mathrm{Zn}, \mathrm{Cu}, \mathrm{Cd}, \mathrm{Pb}, \mathrm{Mn}$ and $\mathrm{Fe}$ in the various geochemical fractions. 


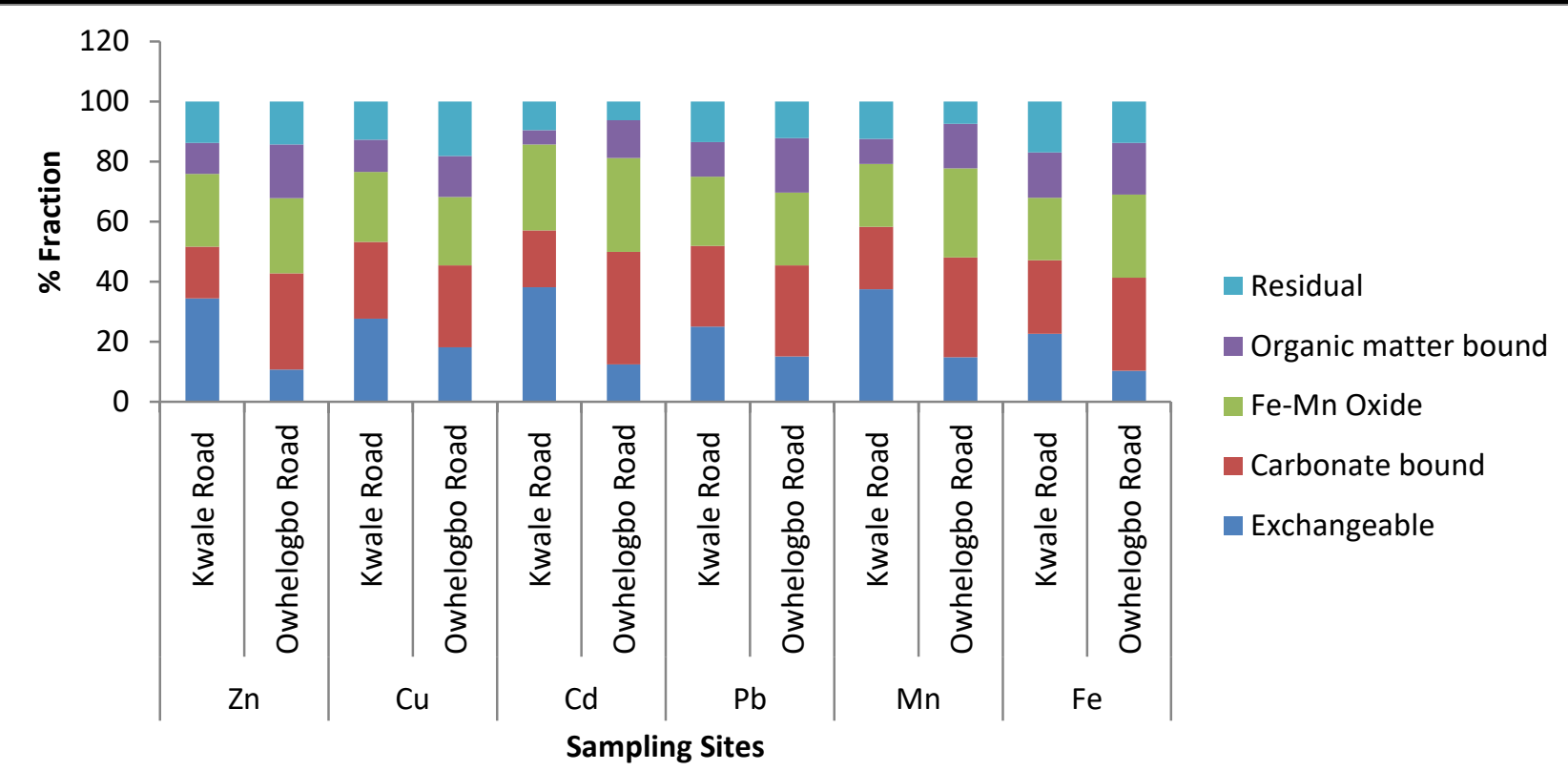

Fig.2: Bar chart showing the Percentage bioavailability of $\mathrm{Zn}, \mathrm{Cu}, \mathrm{Cd}, \mathrm{Pb}, \mathrm{Mn}$ and $\mathrm{Fe}$ in the various geochemical fractions as a function of total metal concentration in soil dump sites.

\section{DISCUSSION}

The $\mathrm{pH}$ result ranged from $9.6-10.3$. The $\mathrm{pH}$ values were basic in both sampling sites. Hydrolysed metal species increases with pH (Mclean and Bledsoe 1992). The electrical conductivity of the sample station could be attributed to the ionic content of the soil (Table 1). The metal concentration for the two sampling stations is in the order: $\mathrm{Fe}>\mathrm{Cu}>\mathrm{Pb}>\mathrm{Zn}>\mathrm{Mn}>\mathrm{Cd}$ for Kwale road and $\mathrm{Pb}>\mathrm{Fe}>\mathrm{Zn}>\mathrm{Mn}>\mathrm{Cu}>\mathrm{Cd}$ for Owhelogbo road (Table 1 and Figure 1).

The exchangeable is the predominant fraction of zinc $(34.48 \%)$ for Kwale road whereas carbonate bound is the predominant fraction $(32.12 \%)$ for Owhelogbo road as shown in Table 2 and 3 and Figure 1 and 2. The results indicate that zinc is readily available. The carbonate associated zinc could be attributed to the relatively high stability constant of $\mathrm{ZnCO}_{3}$ under the $\mathrm{pH}$ - (redox) conditions common in inland water, as it characterises coprecipitation with $\mathrm{CaCO}_{3}$ (CSIRO, 1990; Chakarapani and Subramaman, 1993).

The Fe-Mn oxides formed the next predominant fraction of zinc in both sampling sites $(24.14 \%)$ for Kwale road and $(25.00 \%)$ for Owhelogbo road as shown in Table 2 and 3 and Figure 2 and 3. The association of zinc with Fe-Mn oxides in soils and sediments has been widely reported (Ma and Rao, 1997; Reddy et al., 2001; Gao et. al., 2008; Ekwumemgbo et al.; 2013). Fe-Mn oxides seems to play an essential role in zinc accumulation in the soil as precipitation or co-precipitation products.

Figure 2 and 3 presents the speciation profiles of copper in both sampling sites. The predominant species of copper is associated with the exchangeable fraction
(27.66\%) for Kwale road and carbonate bound fraction $(27.27 \%)$ for Owhelogbo road. The high concentration of copper in the organic matter bound fraction is due to very high values for formation constants of $\mathrm{Cu}$-organic complexes (Stum and Morgan, 1981; Yobout et al., 2010; Obasi et al., 2013). The carbonate bound fraction was the next important fraction of copper $(25.53 \%)$ for Kwale road and Fe-Mn oxide fraction (22.73\%) for Owhelogbo road in this study. Adsorption has been noted as the important control of Copper in soils (Jenne, 1968; Hickey and Kittrick, 1984). The high surface area and adsorbing capacity of Fe-Mn oxide, coupled with the ability of $\mathrm{Cu}^{2+}$ to replace $\mathrm{Fe}^{2+}$ in some Fe-oxides (Taylor, 1965) may be responsible for such adsorption.

The speciation profile of cadmium is presented in Table $2-3$ and Figure 2 and 3. The exchangeable fraction forms the predominant form of cadmium $(38.10 \%)$ and carbonate bound $(37.50 \%)$ for Owhelogbo road.The next dominant fraction of cadmium is associated with Fe-Mn oxide fraction in both sampling locations. The high level of cadmium in this fraction represents the fact that cadmium could be readily remobilised under reducing conditions.

The predominant species of lead is the organic matter bound $(26.92 \%)$ for Kwale road and (30.30\%) for Owhelogbo road as shown in Table $1-2$ and Figure 1 and 2. The next predominant fraction of lead is the exchangeable fraction $(25.00 \%)$ for Kwale road and FeMn oxides fraction (24.24\%) for Owhelogbo road. The result agrees with speciation profile reported by several investigators (Salomon and Forstner, 1980; Tessier et al., 1980; Ryan et al., 2002; Abdus-Salam et al., 2011). The 
result indicates that lead may be remobilized under reducing conditions (Zhang et al., 2003).

The predominant species of Manganese is the exchangeable fraction $(37.50 \%)$ for Kwale road and the carbonate bound $(33.33 \%)$ for Owhelogbo road as shown in Table 1 and 2 and Figure 1 and 2. The association of Manganese with the carbonate fraction agrees with the findings of Asiagwu et al., (2009). The next predominant fraction of manganese is the carbonate bound fraction $(20.83 \%)$ and Fe-Mn oxide $(20.83 \%)$ for Kwale road and Fe-Mn oxides fraction (29.63\%) for Owhelogbo road.

The predominant species of Iron is the carbonate bound $(24.53 \%)$ for Kwale road and (31.03\%) for Owhelogbo road as shown in Table 1 and 2 and Figure 1 and 2. The next predominant fraction of Iron is the exchangeable fraction $(22.64 \%)$ for Kwale road and $\mathrm{Fe}$ Mn oxides fraction (27.59\%) for Owhelogbo road as shown in Table 1 and 2 and Figure 1 and 2. T

The mobility index of metals in the soil may be assessed on the basis of absolute and relative contents of fractions weakly bound to the sediment components. Operationally defined extraction sequence fractionates the metals in order of decreasing solubility, as a result early fraction collected $\left(\mathrm{F}_{1}\right.$ andF $\left.\mathrm{F}_{2}\right)$ captured the most reactive, and presumably most mobile and bioavailable fraction (Iwegbue, 2007). Fe-Mn oxide bound $\left(\mathrm{F}_{3}\right)$ and organic matter bound $\left(\mathrm{F}_{4}\right)$ may become bioavailable if the redox and $\mathrm{pH}$ condition of the soil changes.

The relative index of metal mobility was calculated as a mobility factor (MF) (Salbuet al., 1998; Narwal et al., 1999; Kabala and Singh, 2001; Osakwe, 2010 ) on the basis of the equation given below.$$
M F=F_{1}+F_{2}
$$$$
\overline{\mathrm{F}_{1}+\mathrm{F}_{2}+\mathrm{F}_{3}+\mathrm{F}_{4}+\mathrm{F}_{5}}
$$

Where, $F_{1}=$ Exchangeable; $F_{2}=$ Carbonate bound; $F_{3}=$ Fe-Mn Oxide; $\mathrm{F}_{4}=$ Organic matter bound; and $\mathrm{F}_{5}=$ Residual .

A high MF values for heavy metals in the soil or sediment has been interpreted as evidence of relatively high lability and biological availability (Ma and Rao, 1997; Ahumada et al., 1999; Narwal et al, 1999, Kabala and Singh, 2001). The MF for metal in the sampling sites is given in Table 4. Kwale road showed higher mobility factors than Owhelogbo road. The mobility factors of metals in the soil profile follows in the order: $\mathrm{Cd}>\mathrm{Mn}>\mathrm{Cu}>\mathrm{Pb}>\mathrm{Zn}>\mathrm{Fe}$
Table.3: Mobility factor of heavy metals in some dump sites in Delta State

\begin{tabular}{|l|l|l|}
\hline \multirow{2}{*}{ Metal } & Sites \\
\cline { 2 - 3 } & Kwale Road & Owhelogbo Road \\
\hline $\mathrm{Zn}$ & 51.72 & 42.86 \\
\hline $\mathrm{Cu}$ & 53.19 & 45.45 \\
\hline $\mathrm{Cd}$ & 57.14 & 50.00 \\
\hline $\mathrm{Pb}$ & 51.92 & 45.45 \\
\hline $\mathrm{Mn}$ & 58.33 & 48.15 \\
\hline $\mathrm{Fe}$ & 47.17 & 41.38 \\
\hline
\end{tabular}

\section{CONCLUSION}

This study on the bioavailability of some heavy metals in some waste dumpsites in Ozoro, South-South, Nigeria has revealed the bioavailability of the metals in the various geo-chemical forms. The Exchangeable formed the predominant fraction of zinc, Copper, cadmium, lead and Manganese in Kwale road while carbonate bound fraction was predominant for Zinc, copper, cadmium, lead, manganese and Iron in Owhelogbo road sampling site. Iron and lead were more associated with carbonate bound fraction in both sampling locations. Kwale road showed a higher mobility factors than Owhelogbo road (Table 3).

\section{RECOMMENDATION}

Dumpsites contribute tremendously to the contamination/pollution of soil around the designated sites. This situation demands control because the level of generation of waste is ever on the increase. As a result the following recommendations are made.

I. Dumpsites should be sited far away from residential area

II. Appropriate disposal methods for recycling and reuse should be adopted.

III. The agency on the environment should continue its monitoring activities to ensure safe guideline limit compliance by all and sundry.

\section{REFERENCES}

[1] Abdus-Salam, N., Ibrahim, M. S. and Fatoyinbo, F. T. (2011). Dumpsites in Lokoja, Nigeria: A silent Pollution zone for Underground water. Waste Management and Bioresource Technology 1:21-30.

[2] Abeh, T., Gungshikand, J. And Adamu, M. M. (2007). Speciation studies of trace elements in sediment from Zaramaganda Stream in Jos,

Plateau State, Nigeria. Journal Chem. Soc. Nigeria, 32(2):218-225.

[3] Adelekan, B. A. and Abegunde, K. D. (2011). Heavy metals contamination of soil and groundwater at automobile mechanic villages in Ibadan, Nigeria. Inter. Journal of the Physical Sciences. 6(5):10451058. 
[4] Ahumada, I., Mendoza J. and Ascar I. (1999). Sequential extraction in soils irrigated with wastewater, Communication in Soil Science and Plant Analysis, 30:1057-1079.

[5] Asiagwu, A.K, Ilabor, S.C, Omuku, P.E and Onianwa, P.C (2007). Concentration and speciation patterns of some heavy metals in stream sediments in an urban city in Nigeria. Biosciences, Biotechnology Research Asia 4(2)513-520.

[6] Ataikiru, H, Uwumarongie E.G and Okieimen, F.E (2008). Concentration and Mobility of Heavy Metals in Urban Soils in Warri, Nigeria. Proceeds of the Chemical Society of Nigeria $31^{\text {st }}$ Annual International conference and Exhibition Held in PTI 22nd - 26th September, 2008 pp 698-704.

[7] Bernhard, T. and Neff, J. (2001). Metal Bioavailability in the Navy's Tiered Ecological Risk Assessment Process. Issue Papers, pp.1-15.

[8] Bin, L., Qinquan, W., Benli, H. and Shuping, L. (2001). Evaluation of the results from a QuassiTessier's Sequential extraction procedure for heavy metal speciation in soils and sediments by ICP-MS. JJAC, 17:1561-1563.

[9] Chakrapani, G. J. and Subramanian, V. (1993). Heavy metals distribution and fraction in sediment of the mahadi river basin. India Environmental Geology 22:80-87.

[10]CSIRO (1990). Third Annual Report to the Electricity Commission of NSW on the fluvial transport of trace metal from power station. Fuel and Technology Division, North Ryde, NSW.

[11]Ekwumemgbo, P. A., Omoniyi, K. I. and Sanni, H. A. (2013). Chemical Fractionation of copper, manganese and zinc in dumpsite soil samples in Kaduna Metropolis, Nigeria. American chemical Science Journal 4(2): 138-150.

[12] Gao X., Chen, S., and Long, A., (2008). Chemical speciation of twelve metals in surface sediments from the Northern South China Sea under natural grain size. Baseline/Marine Pollut. Bull 56:770 -797.

[13] Hickey, M. G and Kittrick, J. A. (1984). Chemical Partition of cadmium, copper, Nickel and Zinc in soil and sediments containing high levels of heavy metals. Journal of Environmental Quality 13(3):371-376.

[14] Hlavay, J., Prohaska, T., Weisz, M., Wenzel, W. W., and Stingeder, J. G (2004). Determination of trace elements bound to soils and sediment fractions. Pure Appl. Chem., 76(2):415-442.

[15] Irene, M.C Lo and Yang, X.Y (1998). Removal and Distribution of Metals from Contaminated Soils by a Sequential Extraction Method.Waste management 18:1-7.
[16] Iwegbue, C. M. A. (2007). Metal fractionation in soil profiles at automobile mechanic waste. Waste manage. Res. 25: 1-9.

[17] Jenne, E. A. (1968). Controls of $\mathrm{Mn}, \mathrm{Fe}, \mathrm{Co}, \mathrm{Ni}, \mathrm{Cu}$, and $\mathrm{Zn}$ concentration in soil and water. The significant role of hydrous $\mathrm{Mn}$ Fe oxides in Gould, R. F. (ed). Trace inorganic in water. Advances in Chemistry series No. 73. American Chemical Society, Washinton DC pp337-387.

[18] Kabala, C. and Singh, B. R (2001). Fractionation and mobility of copper, lead and zinc in soil profiles in the vicinity of a copper smelter. J. Environ. Qual. 30, 485-492.

[19] Kot, A and Namiesnik, (2000). Trends Analytical, 19:69-79.

[20] Ma, L. Q. and Rao, G. N. (1997). Chemical fractionation of cadmium, copper, Nickel and zinc in contaminated soil. Journal of Environmental Quality: 26: 259-264.

[21] Mclean, J. E. and Bledsoe, B. E. (1992). Groundwater issue: behaviour of metals in soil. US Env. Prot. Agency, EPA//540s-92/018 October, 1992.

[22] Narwal, R. P., Singh, B. R. and Salbu, B. (1999). Association of cadmium, zinc, copper and nickel with components in naturally heavy metals rich soils studied by parallel and sequential extraction. Communication in Soil Science and Plant Analysis, 30:1209-1230.

[23] Obasi, N. A., Akubugwo, E. I., Kalu, K. M., and Ugbogu, O. C. (2013). Speciation of Heavy metals and Phyto-accumulation potentials of selected plants on major dumpsites in Umuahia, Abia State, Nigeria. International Journal of Current Biochemistry Research 1(4): 16 - 28.

[24] Omuku, P, Asiagwu, A.K and Okeke, J.J, Okoye P.A.C (2009).Heavy Metal Speciation Patterns in Refuse Dumpsites of Awka City, Nigeria. J.Chem. Soc. Nigeria 34(2):17-23.

[25] Osakwe S.A and Egharevba F (2008). Sequential fractionation of cadmium, copper, Lead and Chromium in soils around Municipal solid waste dumps in Agbor, Nigeria. J.Chem.soc. Nigeria 33(2):139-147.

[26] Osakwe, S. A. (2010). Chemical Speciation and Mobility of Some Heavy Metals In Soils around Automobile Waste Dumpsites in Northern Part Of Niger Delta, South Central Nigeria. J. Appl. Sci. Manage. 14(4):123 -130.

[27] Oviasogie, P. O., and Agbimien, A. E. (2003). Macronutrient status and speciation of copper, iron, zinc and lead in soil containing Palm Oil Mill Effluent. Global Appl. Chem., 9(1):71-79. 
[28] Ryan, P. C., Wall, A. J., Hiller, S. and Clark, L. (2002). Insights into sequential chemical extraction procedure for quantitative XRD: A study of trace metal partitioning in soils and sediments related to frog malformation. Chemical Geology, 184:337-357.

[29] Reddy, K. R. and Chinthamreddy, S. (2000). Comparison of extractants for removing heavy metals from contaminated clayey soils. Soil and Sediment Contamination, 9(5):449-462.

[30] Salbu, B. Kreling, T. and Oughton, D. H. (1998). Characterization of radioactive particles in the environment. Analyst, 123: 843-849

[31] Solomon, W and Forstner, U. (1980). Trace metal analysis on polluted sediment part 2 evaluation of environmental impact. Environmental Technology letter 1:506-517.

[32] Sparks, D. L. (2003). Environmental Soil Chemistry, 3rd edition. Academic Press.

[33] Stun, W. and Morgan, J. J (1981).Aquatic Chemistry, chemical equilibria and rates in natural water. John Wiley and Son Inc. USA p 1022.

[34] Taylor, S. R. (1965). The application of trace element data to problems of pathology. In Ahern et al (eds). Physics and Chemistry of the earth. Pergamon Press, New York. Pp 133-213.

[35] Tessier, A, Campbell, P.G.C and Bisson, M (1979). Sequential Extraction Procedures for the Speciation of Particulate Trace Metals. Anal. Chem. 51(7) 844851.

[36] Tessier, A, Campbell, P.G.C and Bisson, M (1980). Trace metal speciation in Yamaska and St Fracious River (Quebec). Canada Journal of earth Science 17:90-105.

[37] Tokalioglu, S., Kaetal, S. and Birol, G. (2003). Application of a three-stage sequential extraction procedure for the determination of extractable metal contents in highway soils. Turks. Journal Chem. Soc. Nigeria, 27:333-346.

[38] Uwumarongie, E.G, Okieimen F.E and Uwumarongie, O.H (2008). Spartial Distribution of Arsenic, Chromium and Copper in Contaminated Soils. J. chem soc. Nigeria,33(1):112-121.

[39] Wuana, R. A., Adie, P. A., and Asegh, I. N (2012). Seasonal variation in bioavailabilty of some toxic metals in waste dump soils of Makurdi, NorthCentral Nigeria. Journal of Bioderversity and Environmental Sciences 2(11):7- 12.

[40] Yobouet, Y. A., Adouby, K., Trokourey, A. and Yao, B. (2010). Cadmium, Copper, lead and Zinc speciation in contaminated soils. International Journal of Engineering Science and Technology, 2(5):802-812.
[41]Zhang, M. K., He, Z. E., Stoffella, P. J., Calvert, D. V., Yang. X and Sim, P. L. (2003). Concentration and Solubility of heavy metals in mulch sediments from the St Lucie Estuary, USA. Environmental Geology. 44:1-7. 